\title{
Penyakit Orf Pada Kambing (Studi Kasus di CV Mitra Farm, Bogor, Jawa Barat)
}

\section{Orf Disease in Goats (Case study in CV Mitra Farm, Bogor, West Java)}

\author{
N Kotimah ${ }^{1}$, N Irwani ${ }^{1}, K_{\text {Magfiroh }}{ }^{3}$ \\ ${ }^{1}$ Jurusan Peternakan Politeknik Negeri Lampung, \\ Jln. Soekarno Hatta No 10 Rajabasa Bandar Lampung, 35144 \\ * E-mail korespondensi: naniirwani@polinela.ac.id
}

\begin{abstract}
Goats are livestock that is classified as small ruminants. One of the factors that influence goat productivity is health management. Health management is a disease control process so that livestock productivity can be maximized. One of the goat diseases in CV Mitra Tani Farm is an 'orf' disease. "Orf" is a scab that attacks the area around the goat's mouth. The 'orf' disease is caused by a zoonotic virus. Orf can cause goats to have difficulty in consuming food, so that the goats become thin, and increase morbidity. The purpose of this Final Project was to determine the occurrence of 'orf' disease in goats in CV Mitra Tani Farm. PE goats and pea goats were used as observation material. Observation, interviews, and secondary data collection were used to collect data in the CV. Mitra Tani Farm. Based on the observations of 'orf' disease in CV Mitra Tani Farm can be concluded that the clinical symptoms seen are blisters in the area around the mouth on the edge of the right lip. Orf disease management in the CV. Mitra Tani Farm was cleaning scabs around the mouth and administration of drugs in the form of gusanex ${ }^{\circledR}$ and vitamin B-complex.
\end{abstract}

Keywords: Goat, orf disease, management

Diterima: $\quad$ Disetujui:

\section{PENDAHULUAN}

Kambing adalah hewan ternak yang tergolong ruminansia kecil yaitu hewan mamalia yang menyusui anaknya dan bertubuh kecil. Kambing dipelihara dengan beberapa sistem yaitu sistem intensif, ekstensif, dan semi intensif. Salah satu faktor yang mempengaruhi produktivitas kambing adalah manajemen kesehatan. Manajemen kesehatan adalah proses pengendalian penyakit agar produktivitas ternak dapat dimaksimalkan dan produk hasil ternak memiliki kualitas yang sesuai dengan standar yang diinginkan. Penyakit tidak hanya mengakibatkan kerugian ekonomis karena menurunnya produktivitas ternak, namun dapat menurunkan minat peternak untuk mengembangkan usahanya.

Salah satu penyakit kambing di CV. Mitra Tani Farm adalah penyakit 'orf'. Penyakit 'orf' adalah penyakit keropeng yang menyerang pada daerah sekitar mulut kambing. Penyakit 'orf' disebabkan oleh virus yang bersifat zoonosis. Penyakit 'orf' dapat menyebabkan kerugian pada peternak kambing. Kerugian yang terjadi yaitu dapat menyebabkan kambing mengalami kesulitan mengkonsumsi pakan, sehingga kambing menjadi kurus serta tingkat morbiditas semakin tinggi dan dapat menularkan ke ternak lain, selain itu penyakit 'orf' juga dapat menyebabkan kerugian lain seperti penurunan produksi, waktu penyembuhan yang lama, tidak ada kemauan untuk bergerak, dan pertumbuhan yang lambat. Penyakit 'orf' 
perlu dilakukan penanganan berkelanjutan dan tepat agar dampak negatif dari penyakit ini dapat diminimalkan (Simanjuntak et al.,1984). Pemahaman kejadian penyakit 'orf' pada kambing di CV. Mitra Tani Farm, Tegal Waru, Ciampea Bogor Jawa Barat perlu dilakukan secara mendalam.

\section{MATERI DAN METODE}

\section{Alat dan Bahan}

Alat yang digunakan adalah sepatu bot, masker, dan sarung tangan. Bahan yang digunakan : vitamin B-kompleks, obat anti lalat berupa gusanex ${ }^{\circledR}$, kambing PE dan kambing kacang.

\section{Metode Pelaksanaan}

Metode pelaksanaan yang digunakan antara lain
a. Observasi, proses pengumpulan data primer dengan memantau, melihat, dan menganalisa secara langsung setiap hari sehingga objek yang diamati akan lebih jelas.
b. Mengamati langsung dengan melakukan pemeliharaan rutin
c. Wawancara, yaitu berkomunikasi dan berdialog langsung dengan pegawai, pembimbing lapang, kepala kandang di CV. Mitra Tani Farm.
d. Pengumpulan data sekunder melalui recording di CV Mitra Tani Farm dan literatur dengan menggunakan sumber-sumber dari berbagai buku

\section{Pengamatan}

Pengamatan yang dilakukan yaitu dengan mengamati dan memahami kejadian penyakit 'orf' pada kambing dengan metode yang diterapkan CV. Mitra Tani Farm, Ciampea Bogor Jawa Barat, diantaranya yaitu: kejadian penyakit 'orf' di CV. Mitra Tani Farm dan penanganan dan pengobatan di CV. Mitra Tani Farm.

\section{HASIL DAN PEMBAHASAN}

\section{Kejadian Penyakit 'orf' di CV. Mitra Tani Farm}

Penyakit 'orf' atau Ecthyma contagiosa adalah jenis penyakit kulit terutama pada ternak kambing. Penyakit ini merupakan penyakit menular yang bersifat zoonosis. Penyakit 'orf' disebabkan oleh virus parapox dan mulai terlihat 2-3 hari setelah kambing datang. Hal ini sesuai dengan pendapat Mulyono (2004), bahwa masa inkubasi virus berlangsung selama 2-3 hari. Masa inkubasi adalah waktu masuknya patogen (penyebab penyakit) ke dalam tubuh sampai menimbulkan gejala pertama kali.

\section{Gejala Penyakit 'orf' di CV. Mitra Tani Farm}

Penyakit 'orf' adalah jenis penyakit keropeng yang menyerang daerah sekitar mulut, kelopak mata, ambing, dan bagian tubuh yang tidak ditumbuhi bulu. Gejala klinis yang terlihat di CV. Mitra Tani Farm yaitu adanya lepuhan di daerah sekitar mulut di bagian pinggir bibir sebelah kanan. Ternak yang terserang penyakit 'orf' terdapat lepuhan di daerah sekitar mulut yang berisi cairan berwarna putih kekuningan, kemudian cairan tersebut pecah dan membentuk keropeng. Ternak yang sakit ditandai dengan kurangnya nafsu makan dan tidak tenang seperti menggesekkan daerah sekitar mulut ke dinding kandang untuk mengurangi rasa gatal. Hal ini sesuai dengan pendapat Darmono (2011) bahwa penyakit 'orf' adalah penyakit kulit yang menyebabkan gejala melepuh pada kulit terutama pada daerah sekitar mulut dan sering menyerang ternak kambing dan domba.

Menurut Mulyono (2004), gejala yang terlihat yaitu sekitar bibir dan lubang hidung terjadi 
peradangan yang menimbulkan benjolan menyerupai bunga kol dan hidung mengeluarkan bau busuk. Peradangan juga dapat terjadi pada ambing, kaki, kelopak mata, dan alat kelamin. Kemudian peradangan akan berubah menjadi lepuh-lepuh dan mengeluarkan cairan dan membentuk kerak. Setelah 7-14, hari kerak mengelupas. Kambing yang terserang penyakit 'orf' mengalami pelepuhan pada daerah di sekitar mulut. Menurut data yang diperoleh, kambing yang terserang penyakit 'orf' di CV. Mitra Tani Farm sebanyak 2 ekor dari populasi 500 ekor. Persentase kambing yang terserang penyakit 'orf' di CV. Mitra Tani Farm adalah $0,4 \%$. Pada keadaan ini perlu pencegahan dan penanganan yang lebih optimal agar penyakit 'orf' tidak terulang kembali. Jika dibiarkan atau tidak ditangani akan terjadi kerugian bagi peternak karena penyakit dapat menular ke ternak lain, ternak menjadi kurus dan dapat menurunkan produktivitas ternak.

\section{Penanganan dan Pengobatan Penyakit 'orf'}

Identifikasi penyakit 'orf' di CV. Mitra Tani Farm dilakukan setelah ternak datang dan diperiksa kembali setelah 3 hari. Pemeriksaan setelah 3 hari terjadi peradangan pada daerah sekitar mulut dan menjadi lepuh-lepuh. Keadaan ini sesuai dengan pendapat Mulyono (2004) bahwa peradangan juga dapat terjadi pada daerah sekitar mulut, ambing, kaki, kelopak mata, dan alat kelamin. Kemudian peradangan akan berubah menjadi lepuh-lepuh dan mengeluarkan cairan dan membentuk kerak. Penanganan penyakit 'orf' di CV. Mitra Tani Farm yaitu dengan membersihkan keropeng pada sekitar mulut. Caranya adalah memisahkan ternak sakit atau diisolasi dari ternak yang sehat, membersihkan keropeng pada daerah sekitar mulut dengan mengupas keropeng tersebut hingga berdarah, kemudian menyemprotkan obat gusanex ${ }^{\circledR}$ di daerah sekitar mulut. Menurut Adjid (2009), pada ternak yang menderita penyakit 'orf' diisolasi dari ternak sehat, keropeng di daerah sekitar mulut dibersihkan hingga berdarah dan diolesi iodin, kemudian diulang setelah 3 hari.

Keropeng dibersihkan kemudian menyemprotkan obat anti lalat pada daerah keropeng tersebut. Obat anti lalat yang digunakan adalah gusanex ${ }^{\circledR}$ yang mengandung $1 \%$ dichlofenthion. Menurut PT. Pimaimas Citra (2008), kandungan $1 \%$ dichlofenthion memiliki beberapa manfaat yaitu kemampuan insektisida dan larvasida, mengandung antiseptik untuk meningkatkan penyembuhan, dan mampu mengusir lalat. Penggunaan $1 \%$ dichlofenthion yang sedikit tidak berbahaya bagi ternak. Hal ini sesuai dengan pendapat Abu Elzein et al. (1997) bahwa obat anti lalat dianjurkan penggunaannya pada penyakit 'orf' untuk mencegah miasis oleh larva lalat. Cara pengaplikasian gusanex ${ }^{\circledR}$ adalah dengan membersihkan keropeng pada daerah sekitar mulut, kocok gusanex ${ }^{\circledR}$ dengan pelan, kemudian semprotkan pada daerah sekitar mulut secara merata dalam posisi tegak dengan jarak $10 \mathrm{~cm}$ dari luka hingga basah. Selain pemberian gusanex ${ }^{\circledR}$, ternak yang sakit di CV. Mitra Tani Farm juga diberi vitamin B-kompleks untuk membantu penyembuhan penyakit, pertumbuhan ternak, dan kekebalan tubuh ternak. Dosis pemberian B-kompleks yaitu $1 \mathrm{ml} / 10 \mathrm{~kg}$ bobot ternak melalui injeksi intramuskular pada paha. Hal ini sesuai dengan pendapat Adjid (2010) bahwa penanganan penyakit 'orf' dilakukan secara simptomatis untuk mencegah infeksi sekunder oleh bakteri dan miasis oleh larva serta mempercepat kesembuhan, seperti penggunakan antibiotik berspektrum luas dan pemberian multivitamin. Bakteri yang berperan sebagai infeksi sekunder yaitu Staphylococcus aureus, S. epidermis dan Corynebacterium pyogenes.

\section{Pencegahan}

Pencegahan penyakit adalah segala tindakan yang dilakukan untuk melindungi tubuh ternak sebelum penyakit menyerang ternak. Tujuan pencegahan penyakit adalah untuk menekan perkembangan penyakit, memperlambat penyakit dan melindungi tubuh ternak dari pengaruh yang berbahaya. Salah satu upaya yang dilakukan untuk mencegah terjadinya penyakit 'orf' di CV. Mitra Tani Farm adalah dengan menjaga kebersihan kandang dan lingkungan sekitar. Kebersihan kandang yaitu dengan cara sanitasi kandang serta mencuci kandang dengan air bersih, menjaga kandang tidak lembab dan tidak tergenang air. Hal ini sesuai 
pendapat Sarwono (2009) bahwa kambing yang sakit dipisahkan dengan kambing yang sehat dan kandang hindarkan dari keadaan lembab dan tergenang air.

\section{KESIMPULAN}

Berdasarkan pengamatan kejadian penyakit 'orf' di CV. Mitra Tani Farm dapat disimpulkan bahwa gejala klinis yang terlihat yaitu adanya lepuhan di daerah sekitar mulut di bagian pinggir bibir sebelah kanan. Penanganan penyakit 'orf' di CV. Mitra Tani Farm dengan membersihkan keropeng pada sekitar mulut serta pemberian obat anti lalat berupa gusanex ${ }^{\circledR}$ dan vitamin B-Kompleks.

\section{DAFTAR PUSTAKA}

Abu Elzein, E.M.E, Gameel, A.A., Al Afaleq, A.I., Al Gundi, O., dan Bukhari, A. 1997. Bovine epheral fever in Saudi Arabia. Veterinary Record. 140 : 630-631.

Adjid, R.M.A. 2009. Penyakit 'orf' pada Ternak Kambing dan Domba Serta Cara Pengendaliannya di Indonesia. Wartazoa. 3(1) : 7-10. 2010. Studi Penyakit 'orf' (dakangan) di Indonesia : Isolasi Virus Penyebab Pada Biakan Sel Domba. Penyakit Hewan. 24(44) : 85-92.

Darmono, H. 2011. Penyakit Utama yang Sering Ditemukan pada Ruminansia Kecil (Kambing dan Domba). Workshop Nasional Diverifikasi Pangan Daging Ruminansia Kecil.

Effriyansyah, Y. 2012. Sanitasi Kandang Ternak. Program Peternakan Fakultas Pertanian Universitas Sriwijaya. Indramayu.

Mulyono, S. 2009. Teknik Pembibitan Kambing dan Domba. Penebar Swadaya. Jakarta. 2009. Ternak Pembibitan Kambing dan Domba. Penebar Swadaya. Jakarta.

Mulyono, S. dan B. Sarwono. 2010. Penggemukan Kambing Potong. Penebar Swadaya. Jakarta.

Prabowo, A. 2010. Budidaya Ternak Kambing. Balai Pengkajian Teknologi Pertanian Sumatra Selatan. Palembang.

PT. Pimaimas Citra. 2018. Aturan Pakai Gusanex. PT Pimaimas Citra. Jakarta.

Sarwono, B. 2009. Beternak Kambing Unggul. Penebar Swadaya. Jakarta. 